\title{
Autoimmune Encephalitis Related to Cancer Treatment with Immune Checkpoint Inhibitors: Systematic Review
}

\author{
Vardan Nersesjan, ${ }^{1 *}$ Oskar McWilliam, ${ }^{1 *}$ Lars-Henrik Krarup, ${ }^{1}$ Daniel Kondziella ${ }^{1,2}$ \\ ${ }^{1}$ Department of Neurology, Rigshospitalet, Copenhagen University Hospital, Copenhagen, \\ Denmark \\ ${ }^{2}$ Department of Clinical Medicine, Faculty of Health and Medical Sciences, University of \\ Copenhagen, Copenhagen, Denmark
}

* Contributed equally

Corresponding author:

Daniel Kondziella, MD, MSc, Dr philos, FEBN

Rigshospitalet, Copenhagen University Hospital

Department of Neurology

DK-2100 Copenhagen

E-mail: daniel kondziella@yahoo.com

$+4535456368$

Submission Type: Systematic Review

Title character count: 104

Number of Tables: 4

Number of Figures: 2 (plus 1 supplemental)

Word count: 3862 (abstract 250)

Financial Disclosures: The authors have no disclosures to declare.

Study funding: None

Patient consent: Patient consent for Figure 1 was obtained.

This review was pre-registered at PROSPERO:

https://www.crd.york.ac.uk/prospero/display record.php?RecordID=139838. 


\section{ABSTRACT}

BACKGROUND. Immune checkpoint inhibitors (ICPI) are a game changer in the treatment of various metastasized cancers, but emerging reports of adverse events, including ICPI-associated autoimmune encephalitis (ICPI-AIE), are concerning. We aimed to collect all published cases of ICPI-AIE to identify the salient clinical and laboratory features of this disorder.

METHODS. We searched PubMed, The Cochrane Library and Embase for ICPI-AIE cases from the first description in 2015 until 01/2020 using standard bibliographic measures including PRISMA guidelines and pre-registration with PROSPERO (CRD42019139838).

RESULTS. Thirty-nine studies met inclusion criteria, resulting in 54 ICPI-AIE patients (mean age 58.6 years; $43 \%$ females). Common cancers included melanoma (30\%) and non-small cell lung cancer (30\%). Brain metastases were found in 16 patients (30\%). The most frequent ICPI was nivolumab (61\%). Onset of ICPI-AIE occurred on average after 3.5 treatment cycles, but very early and late presentations were common. Non-limbic AIE was roughly twice as frequent as limbic AIE $(p<0.05)$. The most common laboratory abnormalities included bitemporal FLAIR lesions on MRI, continuous slow waves and diffuse slowing on EEG, and monocytic pleocytosis on cerebrospinal fluid analysis. Of note, intraneuronal antibodies were more frequent than neuronal surface antibodies, and logistic regression identified the presence of intracellular antibodies as a significant predictor for lack of improvement after $1^{\text {st }}$ line immunotherapy $(p<0.05)$.

CONCLUSIONS. ICPI-AIE consists of a heterogenous group of conditions. Neurologists will likely encounter ICPI-AIE more often in the future, but important unresolved questions include the exact pathophysiological mechanisms, the epidemiology and the best treatment approaches associated with ICPI-AIE.

\section{INTRODUCTION}

Immune checkpoint inhibitors (ICPI) have revolutionized the treatment of oncological patients. They are approved by the US Food and Drug Administration and the European Medicines Agency for the treatment of various advanced cancers like unresectable malignant melanoma, metastasized non-small cell lung cancer, and triple negative breast cancers. ${ }^{1,2}$ ICPI develop their anti-cancer properties by overriding a crucial mechanisms in the formation of metastatic cancer: Cancer cells usually evade immunosurveillance by activation of immune checkpoint pathways that lead to T lymphocytic Cell (TLC) apoptosis via several proteins, including cytotoxic T lymphocyteassociated Antigen 4 (CTLA-4), Programed Cell Death-1 protein (PD-1) and PD-1 Ligand (PD-L1). By inhibiting CTLA-4, PD-1 or PD-L1, ICPI reinstate the immune system's antitumor response and promote immune-mediated tumor cell elimination. ${ }^{1,3}$

With the success of ICPI treatment, however, has followed evidence of immunological adverse events, notably autoimmune neurological adverse events (Figure 1). ${ }^{4-6}$ These events may affect both the central ${ }^{4}$ and the peripheral ${ }^{6}$ nervous systems. For instance, in 3,763 patients treated with 
ICPI, $1 \%$ experienced neurological adverse events and $0.2 \%$ developed autoimmune encephalitis. ${ }^{4}$ A pharmacological surveillance study of 48,653 treated with ICPI found that $0.51 \%$ developed autoimmune encephalitis (AIE). ${ }^{5}$ Although a rare complication, ICPI-induced AIE is a potentially fatal condition and poses diagnostic challenges. The phenotype of ICPI-induced AIE may differ from classical limbic encephalitis or Anti-N-methyl D-aspartate (anti-NMDA) receptor encephalitis due to different disease-mechanisms and lack of detectable autoantibodies, and it may be challenging to distinguish between ICPI induced AIE and paraneoplastic induced AIE in cancer patients treated with ICPI. ${ }^{3}$

The rapidly increasing use of ICPI in antineoplastic treatment is destined to increase the frequency with which ICPI-associated AIE occurs. Several clinically important features remain poorly understood, however. It is unknown if ICPI-induced AIE is a clearly distinguishable entity in its own right or if it consists of a collection of heterogeneous conditions; if it has primarily a limbic presentation or if it involves extra-limbic areas as well; if neuronal surface or intracellular AIE antibodies are present or absent, and if the recently proposed AIE criteria ${ }^{7}$ are applicable to this disorder. We therefore performed a systematic review of all cases of ICPI-induced AIE published until January 2020 in order to characterize the salient symptoms, clinical findings, laboratory results and outcomes associated with the disease.

\section{METHODS}

\section{Standard protocol approvals, registrations, and patient consent}

We conducted a systematic review of the literature in accordance to the PRISMA guidelines. ${ }^{8} \mathrm{~A}$ PRISMA checklist was completed, and the review protocol was uploaded in PROSPERO (registration number CRD42019139838). Ethical approval was not required for this systematic review. The full protocol including search strings can be found at

https://www.crd.york.ac.uk/prospero/display record.php?RecordID=139838.

\section{Primary and secondary objectives}

Using the patients, intervention, comparison, outcome $\left(\mathrm{PICO}^{9}\right)$ approach, we phrased the following primary research question:

- In patients treated with ICPI (anti-PD-1, anti-PD-L1, and/or anti-CTLA-4) for disseminated malignancy, including systemic cancer, melanoma and hematologic malignancies, who develop rapidly progressive encephalopathy caused by brain inflammation in the absence of an infectious cause (P), are neurological examination and laboratory work-up including CSF analysis, EEG and brain MRI (I) compatible with a pure limbic encephalitis (C) or an encephalitis involving extra-limbic areas $(0)$ ? 
We phrased two secondary research questions:

- In patients with ICPI-associated AIE, does plasma and cerebrospinal fluid (CSF) work-up for known autoimmune / paraneoplastic antibodies reveal the presence of those antibodies?

- Do patients diagnosed with ICPI-AIE during neurological examination and laboratory workup, fulfill criteria for AIE as proposed by Graus et al. ${ }^{7}$ ?

\section{Search strategy}

We evaluated all case reports, cross-sectional or longitudinal, retrospective or prospective observational studies as well as interventional trials reporting on patient history of autoimmune encephalitis following treatment with anti-PD-1, anti-PD-L1 and anti-CTLA-4 monoclonal antibodies.

We included only articles that allowed assessment of patient data at the single-subject level. We excluded articles that concerned patients already used in another article by the same authors (or the same institution). We included studies published in English and listed in Medline (PubMed), Cochrane Central Register of Controlled Trials (The Cochrane Library), and Embase since inception of these databases and up until January 2020.

We evaluated all abstracts and identified eligible studies based on full text review. We included only studies published in English, and reference list of each article was manually searched to identify additional articles. VN and OM performed initial selection and further review. After relevant studies were identified, VN and $\mathrm{OM}$ independently extracted relevant information. Disagreement was settled by LHK and DK. Figure $\mathbf{2}$ visualizes data extraction points.

\section{Patients}

We included adults (age $\geq 18$ years) who were treated with anti-PD-1, anti-PDL-1 or anti-CTLA-4 for disseminated cancer and presented to a health care facility with symptoms suggestive of central nervous system (CNS) involvement and were diagnosed with encephalitis. Patients were included irrespective of co-morbidities, concomitant therapies and previous history of CNS disease.

\section{Target conditions}

The target condition was AIE defined as a subacute onset of working memory deficits, altered mental status or psychiatric symptoms in combination with either seizure activity, CNS focal deficits, CSF pleocytosis or MRI features suggestive of encephalitis, in patients treated with nivolumab, pembrolizumab, atezolizumab, or ipilimumab as monotherapy or in combination. In line with previously proposed criteria for AIE by Graus et al., ${ }^{7}$ we classified patients as having possible AIE, definite autoimmune limbic encephalitis, probable anti-NMDA receptor encephalitis, 
definite anti-NMDA receptor encephalitis, definite acute disseminated encephalomyelitis (ADEM) and probable autoantibody negative encephalitis.

\section{Statistical analysis}

We used SPSS version 26 for statistical analysis. Fischer's exact t-test was used to compare difference in dichotomized data, Mann-Whitney- $U$ was used to analyze continuous data, and logistic regression was applied for outcome analysis of improvement after $1^{\text {st }}$ line therapy. $p<0.05$ was considered statistically significant.

\section{RESULTS}

\section{A. Systematic literature search}

The initial database searches retrieved a total of 603 studies, and 2 studies were manually added when checking reference lists (Figure S1, supplemental files). In total, 39 studies $^{10,11,20-29,12,30-}$ 39,13,40-48,14-19 with 53 individual patients met inclusion criteria; the first study was published in 2015. We included data from the patient in Figure 1, seen at our institution. All studies were case reports or case series reporting on single subject data. No prospective data were available.

\section{B. Patient population}

Of 54 patients included, $57 \%$ were male and the mean age was 58.6 years. Eighty-nine \% had metastasized cancer. The most common cancer diagnoses were melanoma (30\%), non-small cell lung cancer (NSCLC, $30 \%$ ) and renal cell carcinoma (7\%). Brain metastases were found in 16 patients (30\%). The most common ICPI treatment was nivolumab (61\%), and dual ICPI therapy was initiated in 14 patients (26\%). Complete remission of cancer was seen in 5 patients (9\%) after ICPI treatment, positive responses despite incomplete remission in 16 patients (30\%), and in 12 patients (22\%) there was progression of cancer despite ICPI treatment. The mean cycle of ICPI treatments before occurrence of symptoms of presumed AIE was 3.5 (median 3.0). Ten patients (19\%) experienced other autoimmune adverse events such as hypophysitis, dermatological manifestations and neuromuscular affections.

We divided patients in the following (partly overlapping) subgroups: With brain metastases (BM+) $(\mathrm{N}=16)^{11,13,17,23,28,31,33,35,45,4738,41,42,44,46}$, without brain metastases (BM-) (N=38) ${ }^{10,12,24-27,29-}$ $32,34,36,14,37,39,40,42,43,45,46,48,15,16,18-22$, with limbic AIE $(\mathrm{N}=16)^{14,18,46,47,19,22,26,27,34,36,39,42}$ and extra-limbic $\operatorname{AIE}(\mathrm{N}=38)^{10,11,23-26,28-33,12,35,37,38,40-42,44-46,48,13,15-17,20-22}$. Limbic AIE were determined according to criteria for AIE by Graus et al. ${ }^{7}$ One patient had bitemporal FLAIR lesions and anti-Ma2 antibodies present in CSF, but the clinical presentation was not consistent with involvement of the limbic system, there were no CSF pleocytosis or EEG activity suggestive of temporal involvement, and this patient was therefore labelled as having extra-limbic AIE. ${ }^{46}$ 
Theses subgroups (i.e. BM+ vs. BM- and limbic AIE vs. extra-limbic AIE) were compared for differences in demographics, but there were no statistically significant differences. See Table $\mathbf{1}$ for demographics.

\section{Clinical symptomatology}

Table 2 shows an overview of symptoms from the total population and the subgroups. Symptom onset was subacute ( $<3$ months) in all patients except in one patient ${ }^{23}$ who had a sudden onset of symptoms, two patients ${ }^{39,46}$ with slow and progressive course, and one patient ${ }^{13}$ in whom symptom onset was not disclosed. Symptom and signs included, in decreasing frequency, altered mental status (85\%), focal CNS deficits (63\%), psychiatric symptoms (37\%), seizures (33\%), autonomic dysfunction (33\%), working memory deficits (28\%), ataxia (19\%) and dyskinesia (11\%). Of the psychiatric symptoms, behavioral disorders were most frequent (55\%), followed by affective symptoms (35\%), hallucinations (20\%) and paranoia (20\%). Concerning epileptic seizures, generalized seizures were most common (39\%), followed by focal seizures (28\%) and nonconvulsive status epilepticus ( $22 \%$ ). Eleven \% had both generalized and focal seizures. Autonomic dysfunction was described in 13 patients, $2(11 \%)$ of which had central hypoventilation and 12 (67\%) of which had fever.

Working memory deficits were more frequent in patients with limbic AIE ( $N=11,69 \%$ ) than in patients with the extra-limbic AIE ( $N=4,11 \%) p<0.001$. No other symptoms occurred with statistically different frequency in the tested subgroups.

\section{Laboratory findings}

\section{Magnetic resonance imaging}

Fifty-two patients ( $96 \%$ ) were investigated with MRI. 29 patients ( $56 \%$ ) had positive findings, with bitemporal FLAIR lesions (52\%) being the most common followed by multifocal inflammatory lesions of white and/or grey matter (17\%), leptomeningeal enhancement (14\%), lesions of basal ganglia (7\%) and pachy-meningeal enhancement (7\%). One patient had a unilateral temporal FLAIR lesion ${ }^{47}$ and one patient had a not further specified lesion. ${ }^{31} \mathrm{MRI}$ lesions were found in all patients with limbic-AIE, but only in 13 patients $(36 \%)$ of the extra-limbic group $(p<0.001)$. See Table 3 for laboratory findings.

\section{Electroencephalogram}

EEG was performed in 25 (46\%) patients, of which 19 (76\%) had abnormal findings consisting of continuous slow waves (21\%), diffuse slowing (21\%), frontal intermittent delta activity (FIRDA) (16\%) and (non-convulsive) status epilepticus (16\%).

\section{Lumbar puncture}


CSF was analyzed in 51 patients (94\%) of which 34 patients (67\%) had pleocytosis (defined as $>5$ white blood cells/microL) with a median of 18 white blood cells/microL. Patients with limbic AIE had the same frequency of CSF pleocytosis but significantly fewer cells in the CSF compared to patients with extra-limbic AIE (median 16 vs. 53 white blood cells/microL, p<0.05). Cell differentiation in CSF was mostly lymphocytic (68\%). Four patients (12\%) had predominantly granulocytes and all of these were in the extra-limbic group. Oligoclonal bands were searched for in 17 patients ( $33 \%$ ), and $53 \%$ of those were positive. Patients in the limbic AlE group were more frequently tested for oligoclonal bands compared to those from the extra-limbic AIE group (60\% vs. $22 \%, p<0.05$ ), but there was no difference in frequency of positive oligoclonal bands between the groups.

Table 4 shows an overview of antibody testing. Antibody testing for antibodies against cell-surface or intracellular antigens was performed in $57 \%$ (CSF) and $46 \%$ (blood) of patients, respectively. Of those tested, $55 \%$ and $48 \%$ had positive findings in CSF and blood, respectively. Antibodies against intracellular antigens in CSF were most frequent: anti-Ma2 antibodies occurred in eight patients $^{30,43,46}(47 \%)$, anti-Hu in two patients ${ }^{26,27}(12 \%)$, anti-GAD in two patients ${ }^{18,42}(12 \%)$, an unspecified Purkinje cell antibody in one patient ${ }^{27}(6 \%)$ and anti-Ri in another one ${ }^{26}(6 \%)$. One patient $^{27}$ had both anti-HU and an unspecified Purkinje cell antibody. Antibodies against cellsurface antigens were less frequent and only seen in three patients; anti-NMDA receptor ${ }^{31,41}$ and contactin-associated protein-like 2 (CASPR2) antibodies. ${ }^{14}$ One patient was described with a novel and unclassified antibody. ${ }^{42}$ Antibodies present in blood followed almost the same pattern of distribution in the population as CSF antibodies, although one patient had anti-glial nuclear antibodies in blood which was not present in $\mathrm{CSF}^{47}$ one patient had positive anti-Hu present in blood before initiation of ICPI treatment, ${ }^{34}$ and one patient had elevated anti thyroid peroxidase antibodies (anti-TPO). ${ }^{16}$

\section{E. Treatment and outcome}

See Table 5 for full outline of treatment and outcome.

\section{First line therapy and outcome}

First line therapy was defined as either steroid, IVIG and/or PEX treatment. Steroid treatment was initiated in 51 patients (94\%), while one patient did not receive any treatment ${ }^{13}$ and two patients ${ }^{12,31}$ were already on steroid treatment which was not increased. Four patients were only treated with oral steroids, ${ }^{22,35,41,47} 35$ patients received iv pulse therapy of which 23 were given high dose treatment ( $>500 \mathrm{mg}$ daily), and in 12 patients (22\%) steroid dosage was not disclosed. IVIG was initiated in 15 patients (28\%). One patient received repeated IVIG treatment. ${ }^{29}$ PEX was initiated in 7 patients ${ }^{15,18,34,42,46}$, including the patient in Figure 1 (13\%). All patients treated with either IVIG or PEX, received concomitant steroid treatment. Only two patients received steroids, IVIG and PEX treatment. ${ }^{18,42}$ 
Improvement after first line therapy was seen in 35 patients (69\%), progression of symptoms in 14 patients (27\%), and 2 patients (4\%) had no change in symptoms after first line therapy. Nine out of 12 patients with progression were started on second line therapy.

\section{Second line therapy and outcome}

Second line therapy was defined as immunosuppressive agents other than steroids, IVIG or PEX, and was initiated in 14 patients (26\%). Eight patients were treated with rituximab, ${ }^{26,28,31,36,42,46}$ one patient with natalizumab, ${ }^{27}$ two patient with cyclophosphamide, ${ }^{31,45}$ two patients with infliximab, ${ }^{25,30}$ one patient with mycophenolate, ${ }^{19}$ and one patient with azathioprine (figure 1). One patient received both rituximab and cyclophosphamide. ${ }^{31}$

Improvement after second line therapy was seen in seven patients ${ }^{25-28,31,42,}$, including the patient in Figure 1, progression in five patients ${ }^{26,30,36,42}$, and no change in symptoms in two patients. ${ }^{19,45}$

\section{Admission duration, intensive care, relapse and mortality}

Data on the length of admission was available for 25 patients (46\%) and median of days admitted was 21 (range 5-182). Treatment in an intensive care unit setting was described in nine patients ${ }^{31-}$ $3426,40,44,48$, including the patient in Figure $1(17 \%)$, and five patients ${ }^{18,19,25,26,36}(9 \%)$ experienced a relapse of AIE.

Sequalae after admission was described in 14 patients: Prolonged cognitive deficits were most frequent (79\%). Death occurred in 19 patients (35\%) of which 10 patients ${ }^{13,26,31,34,36,42,46}$ died with/of their presumed AIE, and in nine patients ${ }^{12,17,18,31,33,39,47}$, including the patient in Figure 1, death was attributed to progression of their underlying cancer.

\section{F. Diagnosis of autoimmune encephalitis}

Following application of the AIE criteria proposed by Graus et al., ${ }^{7} 23$ patients $^{11,17,32,33,35,37,38,40,44,46,20-23,28-31}$ fulfilled the criteria for possible AIE; 16 patients $^{14,18,43,46,47,19,22,26,27,34,36,39,42}$, including the one in Figure 1, criteria for limbic AlE; two patients $^{31,41}$ criteria for definite anti-NMDA AlE; two patients ${ }^{10,45}$ criteria for probable autoantibody negative AIE, one patient ${ }^{16}$ criteria for Hashimoto's encephalopathy (aka. steroid responsive encephalopathy associated with autoimmune thyroiditis, SREAT); and one patient ${ }^{48}$ met criteria for definite acute disseminated encephalomyelitis (ADEM).

Adhering strictly to the proposed criteria, we found nine patients ${ }^{12,13,15,24-26,32,42,46}$ who did not meet the criteria for the following reasons: Four patients ${ }^{12,13,15,46}$ presented with cognitive symptoms of either altered mental status, psychiatric symptoms or working memory deficits but no seizures, focal CNS findings or paraclinical signs of CNS inflammation (although one ${ }^{32}$ showed non-infectious encephalitis with brainstem involvement on post-mortem autopsy). Two 
patients ${ }^{24,26}$ had focal CNS findings and CSF pleocytosis but no altered mental status, psychiatric

symptoms or working memory deficits. One patient ${ }^{42}$ had focal hemiballismus and MRI changes of the basal ganglia but no altered mental status, psychiatric symptoms or working memory deficits. One patient ${ }^{25}$ presented with headache and flu-like symptoms with meningeal enhancement on MRI suggestive of aseptic meningitis. One patient ${ }^{46}$ was described with ophthalmoplegia and head-drop suggestive of affection of the peripheral nerve system without cognitive or any other symptoms suggesting limbic involvement, although MRI showed bitemporal FLAIR lesions.

Table 6 presents paraclinical findings and outcome in the population divided in subgroups according to the proposed criteria by Graus et al. ${ }^{7}$ A logistic regression was performed to assess if age, sex, presence of brain metastases, presence of intracellular antibodies in CSF and grouping according to Graus et al. ${ }^{7}$ criteria had an effect on improvement after $1^{\text {st }}$ line therapy. We found that the presence of intracellular antibodies was a significant predictor for lack of improvement after $1^{\text {st }}$ line therapy $(p<0.05)$, but the other variables were non-significant.

\section{DISCUSSION}

We collected all cases ( $n=54$ ) of ICPI-associated AIE published since the first description of the entity in 2015 until January 2020. The high number of case reports and case series that have emerged within this comparatively short time period, as well as the wide geographic distribution with reports from the Americas, Europe and Australasia, suggests that ICPI-AIE is a widespread and relevant disorder that neurologists are increasingly likely to encounter in clinical practice.

Several key messages are available for the clinician from this review. First, in patients treated with ICPI for disseminated malignancies, both non-limbic and limbic AIE may arise, but non-limbic AIE presentation is roughly twice as common as limbic AlE. Second, only roughly half of the patients tested have known neuronal antibodies, either in CSF or in blood; but of note, classical intracellular antibodies are more frequent than surface antibodies, perhaps reflecting the paraneoplastic nature of ICPI-associated AIE. Third, AIE criteria as recently proposed by Graus et al. ${ }^{7}$ are applicable to most cases of ICPI-AIE, but we identified 9 of 54 patients who did not meet these criteria for a variety of reasons, so clinical acumen is needed to make a diagnosis of AIE in ICPI treated patients.

Also, the clinical outcome after ICPI-AIE ranged from mild to severe, including the need for intensive care management and death. Of note, presence of intracellular antibodies was a significant predictor for lack of improvement after $1^{\text {st }}$ line therapy. Overall, however, the underlying cancer is probably the most crucial determinant of survival and morbidity.

Other clinically important messages include the male-female ratio, which was roughly $1: 1$, so ICPIassociated AIE is unlikely to be sex-specific. Importantly, brain metastases were found in 16 patients $(30 \%)$, and the presence of cancer spread to the CNS may pose a particular diagnostic 
challenge as the clinician must decide which signs and symptoms are attributable to AIE and which to the tumor. Also, it must be kept in mind that the average cycle of ICPI treatments before occurrence of symptoms of presumed AIE was 3.5, but very early and very late presentations are possible, and the reasons for this variance are unknown.

Altered mental status appears to be the most frequent presentation in ICPI-AIE, and seizures less so, but seizures and other findings might be underreported given the retrospective nature of the present study. Working memory deficits were more frequent in patients with limbic AIE than in patients with the extra-limbic AIE, which may be explained with the prominent hippocampal involvement in limbic AIE. Laboratory abnormalities comprised a wide range from normal to abnormal. Most frequent were EEG changes, including localized and generalized and epileptiform and non-epileptiform activity, but none of this is specific to ICPI-AIE. CSF pleocytosis appeared equally common in limbic and extra-limbic AIE, but the cell count was less in limbic AIE perhaps reflecting more restricted inflammation. ICPI-associated AIE was most frequent with nivolumab but it is unknown whether nivolumab is particularly prone to inducing AIE or if this simply reflects the more widespread use of it; and it is important to be aware of that AIE may arise with various ICPI, including various combinations of ICPI. Finally, given that ICPI is associated with several AIE presentations, including limbic, non-limbic, SREAT and ADEM, this suggests that the immunological adverse events of ICPI can affect both gray and white matter in different brain regions. This tendency to involve various anatomical sites mirrors what is known of ICPI adverse events affecting the peripheral nervous system; here too, all structures can potentially be involved, including peripheral neurons, neuromuscular junctions and muscle cells. ${ }^{6}$

Reviewing the current data raises important questions, not the least about the pathophysiology of ICPI-associated AlE. For instance, why do some patients experience symptoms after just a single dose of ICPI, while others go through several cycles before AIE onset? Why do some patients develop limbic AIE, while others (the majority) have extra-limbic AIE? What are the molecular targets in antibody-negative patients with atypical presentations or laboratory findings? Exactly how much of the morbidity and mortality are due to AIE and how much to the cancer itself? What is the most appropriate treatment of ICPI-AIE, and should ICPI be discontinued? Future studies are needed to define mechanism and best treatment approaches, but for the time being it seems fair to conclude that neurologists need a high clinical suspicion to identify patients with ICPI-AIE as treatment delay is likely to lead to increased morbidity and mortality.

Systematic reviews like this are prone to certain limitations that should be acknowledged. We may have underestimated the true frequency of AIE characteristics, given that absence of reported signs and symptoms in individual case reports is not necessarily evidence for their factual absence. Consequently, we cannot conclude with confidence if diagnostic inconsistencies are due to inadequate workup or misinterpretation of results. Further, we were unable to quantify treatment effects and mortality compared with non-ICPI AIE because the data lacked sufficient detail and 
direct comparisons between ICPI-AIE and non-ICPI-AIE are unavailable. Moreover, the effects of metastatic cancer itself may be difficult to distinguish from severe autoimmune disease, requiring further study.

To summarize, the high number of reports on ICPI-AIE that have emerged within the past 5 years suggests that neurologists are increasingly likely to see this disorder in their daily practice. While both limbic and non-limbic AIE presentations are common, the latter is even more frequent. Intraneuronal antibodies are more common than neuronal surface antibodies, and data indicate that presence of intraneuronal antibodies may negatively affect AIE treatment response. Finally, many important questions remain, in particular related to pathophysiological mechanisms, clinical symptomatology and treatment. Thus, autopsy studies are needed to define mechanisms; prospective registry studies are required to define prevalence; and randomized clinical trials are important to establish the best treatment options in ICPI-associated AIE. 


\section{Reference list}

1. Darvin P, Toor SM, Sasidharan Nair V, Elkord E. Immune checkpoint inhibitors: recent progress and potential biomarkers. Exp Mol Med. 2018;50:165.

2. Yarchoan M, Hopkins A, Jaffee EM. Tumor Mutational Burden and Response Rate to PD-1 Inhibition. N Engl J Med. 2017;377:2500-2501.

3. Dalakas MC. Neurological complications of immune checkpoint inhibitors: what happens when you 'take the brakes off' the immune system. Ther Adv Neurol Disord. 2018;11:175628641879986.

4. Larkin J, Chmielowski B, Lao CD, et al. Neurologic Serious Adverse Events Associated with Nivolumab Plus Ipilimumab or Nivolumab Alone in Advanced Melanoma, Including a Case Series of Encephalitis. Oncologist. 2017;22:709-718.

5. Johnson DB, Manouchehri A, Haugh AM, et al. Neurologic toxicity associated with immune checkpoint inhibitors: a pharmacovigilance study. J Immunother cancer. BioMed Central; 2019;7:134.

6. Johansen A, Christensen SJ, Scheie D, Højgaard JLS, Kondziella D. Neuromuscular adverse events associated with anti-PD-1 monoclonal antibodies. Neurology [online serial]. Epub 2019 Mar 8.:10.1212/WNL.0000000000007235. Accessed at: http://www.neurology.org/lookup/doi/10.1212/WNL.0000000000007235. Accessed March 18, 2019.

7. Graus F, Titulaer MJ, Balu R, et al. A clinical approach to diagnosis of autoimmune encephalitis. Lancet Neurol. 2016/02/20. 2016;15:391-404.

8. Mclnnes MDF, Moher D, Thombs BD, et al. Preferred Reporting Items for a Systematic Review and Meta-analysis of Diagnostic Test Accuracy Studies The PRISMA-DTA Statement. JAMA - J Am Med Assoc. American Medical Association; 2018;319:388-396.

9. Schardt C, Adams MB, Owens T, Keitz S, Fontelo P. Utilization of the PICO framework to improve searching PubMed for clinical questions. BMC Med Inform Decis Mak [online serial]. 2007;7:16. Accessed at:

http://www.pubmedcentral.nih.gov/articlerender.fcgi?artid=1904193\&tool=pmcentrez\&re ndertype=abstract. Accessed January 4, 2015.

10. Altunrende B, Nalbantoglu M, Gungor Tuncer O, Matur Z, Topcular B, Akman Demir G. Assosciation of autoimmune encephalitis with immune checkpoint inhibitor. J Neurol Sci. Elsevier BV; 2017;381:529.

11. Arakawa $\mathrm{M}$, Yamazaki $\mathrm{M}$, Toda $\mathrm{Y}$, et al. Atezolizumab-induced encephalitis in metastatic lung cancer: a case report and literature review. eNeurologicalSci Elsevier B.V.; 2019. p. 4950 . 
12. B C, A S, A D, SM S. Nivolumab-Induced Encephalitis in Hereditary Leiomyomatosis and Renal Cell Cancer Syndrome. Case Rep Oncol Med. Case Rep Oncol Med; 2018;2018.

13. Bossart S, Thurneysen S, Rushing E, et al. Case Report: Encephalitis, with Brainstem Involvement, Following Checkpoint Inhibitor Therapy in Metastatic Melanoma. Oncologist. Alphamed Press; 2017;22:749-753.

14. Brown MP, Hissaria $\mathrm{P}$, Hsieh AH, Kneebone $\mathrm{C}$, Vallat W. Autoimmune limbic encephalitis with anti-contactin-associated protein-like 2 antibody secondary to pembrolizumab therapy. J Neuroimmunol. Elsevier B.V.; 2017;305:16-18.

15. Burke $M$, Hardesty $M$, Downs W. A case of severe encephalitis while on PD-1 immunotherapy for recurrent clear cell ovarian cancer. Gynecol Oncol Reports. Elsevier B.V.; 2018;24:51-53.

16. Carl D, Grüllich C, Hering S, Schabet M. Steroid responsive encephalopathy associated with autoimmune thyroiditis following ipilimumab therapy: A case report. BMC Res Notes. BioMed Central Ltd.; 2015;8:316.

17. Choe JH, Andonian BJ, Kim GJ, Salama AKS. Autoimmune meningoencephalitis in a melanoma patient treated with ipilimumab. Immunotherapy. Future Medicine Ltd.; 2016;8:1163-1167.

18. Chung M, Jaffer M, Verma N, Mokhtari S, Ramsakal A, Peguero E. Immune checkpoint inhibitor induced anti-glutamic acid decarboxylase 65 (Anti-GAD 65) limbic encephalitis responsive to intravenous immunoglobulin and plasma exchange. J Neurol. Springer; 2020;267:1023-1025.

19. Cordes LM, Davarpanah NN, Reoma LB, et al. Neurotoxicities associated with checkpoint inhibitors: Two case reports and a review of the literature. Clin Case Reports. WileyBlackwell Publishing Ltd; 2020;8:24-32.

20. De la Hoz A, Foolad F, Gallegos C, Kornblau S, Kontoyiannis DP. Nivolumab-induced encephalitis post allogeneic stem cell transplant in a patient with Hodgkin's disease. Bone Marrow Transplant. Nature Publishing Group; 2019. p. 749-751.

21. Dheeraj Kalladka KB. Ipilimumab Induced Encephalitis: A Case Report. Immunome Res. OMICS Publishing Group; 2015;11.

22. Fellner A, Makranz $C$, Lotem $M$, et al. Neurologic complications of immune checkpoint inhibitors. J Neurooncol. Springer New York LLC; 2018;137:601-609.

23. Feng S, Coward J, Mccaffrey E, Coucher J, Kalokerinos P, O’byrne K. Pembrolizumab-Induced Encephalopathy: A Review of Neurological Toxicities with Immune Checkpoint Inhibitors. J Thorac Oncol. 2017;12:1626-1635.

24. Fujiwara S, Mimura N, Yoshimura H, et al. Elevated Adenosine Deaminase Levels in the Cerebrospinal Fluid in Immune Checkpoint Inhibitor-induced Autoimmune Encephalitis. 
Intern Med. Japanese Society of Internal Medicine; 2019;58:2871-2874.

25. Garcia CA, El-Ali A, Rath TJ, et al. Neurologic immune-related adverse events associated with adjuvant ipilimumab: Report of two cases. J Immunother Cancer. BioMed Central Ltd.; 2018;6:83.

26. Gill AJ, Perez MA, Perrone CM, Bae CJ, Pruitt AA, Lancaster E. A case series of PD-1 inhibitorassociated paraneoplastic neurologic syndromes. J Neuroimmunol. Elsevier B.V.; 2019;334.

27. Hottinger AF, De Micheli R, Guido V, Karampera A, Hagmann P, Du Pasquier R. Natalizumab may control immune checkpoint inhibitor-induced limbic encephalitis. Neurol. Neuroimmunol. Neurolnflammation Lippincott Williams and Wilkins; 2018.

28. Ito M, Fujiwara S, Fujimoto $D$, et al. Rituximab for nivolumab plus ipilimumabinduced encephalitis in a small-cell lung cancer patient. Ann. Oncol. 2017. p. 2318-2319.

29. Kim A, Keam B, Cheun H, Lee ST, Gook HS, Han MK. Immune-checkpoint-inhibitor-induced severe autoimmune encephalitis treated by steroid and intravenous immunoglobulin. J Clin Neurol. Korean Neurological Association; 2019;15:259-261.

30. Kopecký J, Kubeček O, Geryk T, et al. Nivolumab induced encephalopathy in a man with metastatic renal cell cancer: A case report. J Med Case Rep. BioMed Central Ltd.; 2018;12:262.

31. Larkin J, Chmielowski B, Lao CD, et al. Neurologic Serious Adverse Events Associated with Nivolumab Plus Ipilimumab or Nivolumab Alone in Advanced Melanoma, Including a Case Series of Encephalitis. Oncologist. Alphamed Press; 2017;22:709-718.

32. Laserna A, Tummala S, Patel N, El Hamouda DEM, Gutiérrez C. Atezolizumab-related encephalitis in the intensive care unit: Case report and review of the literature. SAGE Open Med Case Reports. SAGE Publications; 2018;6:2050313X1879242.

33. Levine JJ, Somer RA, Hosoya H, Squillante C. Atezolizumab-induced Encephalitis in Metastatic Bladder Cancer: A Case Report and Review of the Literature. Clin Genitourin Cancer. Elsevier Inc.; 2017;15:e847-e849.

34. Matsuoka H, Kimura H, Koba H, et al. Nivolumab-induced Limbic Encephalitis with Anti-Hu Antibody in a Patient With Advanced Pleomorphic Carcinoma of the Lung. Clin Lung Cancer. Elsevier Inc.; 2018;19:e597-e599.

35. Niki M, Nakaya A, Kurata T, et al. Pembrolizumab-induced autoimmune encephalitis in a patient with advanced non-small cell lung cancer: A case report. Mol Clin Oncol. Spandidos Publications; 2018;10:267-269.

36. Papadopoulos KP, Romero RS, Gonzalez G, Dix JE, Lowy I, Fury M. Anti-Hu-Associated Autoimmune Limbic Encephalitis in a Patient with PD-1 Inhibitor-Responsive Myxoid Chondrosarcoma. Oncologist. Alphamed Press; 2018;23:118-120. 
37. Quach HT, Robbins CJ, Balko JM, et al. Severe Epididymo-Orchitis and Encephalitis Complicating Anti-PD-1 Therapy. Oncologist. Alphamed Press; 2019;24:872-876.

38. Richard K, Weslow J, Porcella SL, Nanjappa S. A Case Report of Steroid Responsive Nivolumab-Induced Encephalitis. Cancer Control. SAGE Publications Ltd; 2017;24:1073274817729069.

39. Salam S, Lavin T, Turan A. Limbic encephalitis following immunotherapy against metastatic malignant melanoma. BMJ Case Rep. BMJ Publishing Group; 2016;2016:bcr2016215012.

40. Schneider S, Potthast S, Komminoth P, Schwegler G, Böhm S. PD-1 Checkpoint Inhibitor Associated Autoimmune Encephalitis. Case Rep Oncol. S. Karger AG; 2017;10:473-478.

41. Shah N, Jacob J, Househ Z, Shiner E, Baird L, Soudy H. Unchecked immunity: A unique case of sequential immune-related adverse events with Pembrolizumab. J Immunother Cancer. BioMed Central Ltd.; 2019;7:247.

42. Shah S, Dunn-Pirio A, Luedke M, Morgenlander J, Skeen M, Eckstein C. Nivolumab-Induced Autoimmune Encephalitis in Two Patients with Lung Adenocarcinoma. Case Rep Neurol Med. 2018;2018:1-4.

43. Shibaki R, Murakami S, Oki K, Ohe Y. Nivolumab-induced autoimmune encephalitis in an anti-neuronal autoantibody-positive patient. Jpn J Clin Oncol. 2019;49:793-794.

44. Stein MK, Summers BB, Wong CA, Box HL, Cleveland KO. Meningoencephalitis following ipilimumab administration in metastatic melanoma. Am J Med Sci. Lippincott Williams and Wilkins; 2015;350:512-513.

45. Strik H, Keber U, Hammoud WA, et al. Immune checkpoint inhibitor-associated CNS autoimmune disorder (ICICAD) following nivolumab treatment: A new entity of druginduced autoimmune encephalitis? Eur. J. Cancer Elsevier Ltd; 2017. p. 205-208.

46. Vogrig A, Fouret $M$, Joubert B, et al. Increased frequency of anti-Ma2 encephalitis associated with immune checkpoint inhibitors. Neurol Neuroimmunol Neurolnflammation. Lippincott Williams and Wilkins; 2019;6.

47. Williams TJ, Benavides DR, Patrice KA, et al. Association of autoimmune encephalitis with combined immune checkpoint inhibitor treatment for metastatic cancer. JAMA Neurol. American Medical Association; 2016;73:928-933.

48. Zafar Z, Vogler C, Hudali T, Bhattarai M. Nivolumab-associated acute demyelinating encephalitis: A case report and literature review. Clin Med Res. Marshfield Clinic; 2019;17:29-33. 
medRxiv preprint doi: https://doi.org/10.1101/2020.08.31.20185009; this version posted September 2, 2020. The copyright holder for this preprint (which was not certified by peer review) is the author/funder, who has granted medRxiv a license to display the preprint in perpetuity.

It is made available under a CC-BY-ND 4.0 International license .

\section{Tables}

\begin{tabular}{|c|c|c|c|c|c|c|c|c|c|c|}
\hline Demographics & \multicolumn{2}{|c|}{$\begin{array}{l}\text { Total } \\
\text { ( } N=54)\end{array}$} & \multicolumn{2}{|c|}{$\begin{array}{l}\text { Without brain } \\
\text { metastases } \\
\text { (N=38) }\end{array}$} & \multicolumn{2}{|c|}{$\begin{array}{c}\begin{array}{c}\text { With brain } \\
\text { metastases }\end{array} \\
\text { (N=16) }\end{array}$} & \multicolumn{2}{|c|}{$\begin{array}{l}\text { Limbic AIE } \\
\text { ( } N=16)\end{array}$} & \multicolumn{2}{|c|}{$\begin{array}{l}\text { Non limbic AIE } \\
(\mathrm{N}=\mathbf{3 8})\end{array}$} \\
\hline Total of patients, $\mathbf{N}(\%)$ & 54 & $100 \%$ & 38 & $70 \%$ & 16 & $30 \%$ & 16 & $30 \%$ & 38 & $70 \%$ \\
\hline Age (mean) & 58,6 & & 57,2 & & 61,7 & & 56,9 & & 59,3 & \\
\hline Sex, male, $N(\%)$ & 31 & $57 \%$ & 22 & $58 \%$ & 9 & $56 \%$ & 8 & $50 \%$ & 23 & $61 \%$ \\
\hline Metastatic yes, N (\%) & 48 & $89 \%$ & 32 & $84 \%$ & 16 & $100 \%$ & 12 & $75 \%$ & 36 & $95 \%$ \\
\hline Brain metastasis yes, $\mathbf{N}(\%)$ & 16 & $30 \%$ & 0 & $0 \%$ & 16 & $100 \%$ & 3 & $19 \%$ & 13 & $34 \%$ \\
\hline \multicolumn{11}{|l|}{ Cancer diagnosis } \\
\hline Metastatic melanoma, N (\%) & 16 & $30 \%$ & 10 & $26 \%$ & 6 & $38 \%$ & 2 & $13 \%$ & 14 & $37 \%$ \\
\hline NSCLC, N (\%) & 16 & $30 \%$ & 8 & $21 \%$ & 8 & $50 \%$ & 5 & $31 \%$ & 11 & $29 \%$ \\
\hline Renal cell carcinoma, $\mathrm{N}(\%)$ & 4 & $7 \%$ & 4 & $11 \%$ & 0 & $0 \%$ & 1 & $6 \%$ & 3 & $8 \%$ \\
\hline Hodgkin's lymphoma, N (\%) & 3 & $6 \%$ & 3 & $8 \%$ & 0 & $0 \%$ & 1 & $6 \%$ & 2 & $5 \%$ \\
\hline SCLC, N (\%) & 2 & $4 \%$ & 1 & $3 \%$ & 1 & $6 \%$ & 1 & $6 \%$ & 1 & $3 \%$ \\
\hline Other, N (\%) & 13 & $24 \%$ & 12 & $32 \%$ & 1 & $6 \%$ & 6 & $38 \%$ & 7 & $18 \%$ \\
\hline \multicolumn{11}{|l|}{ ICPI Treatment } \\
\hline Nivolumab, N (\%) & 33 & $61 \%$ & 26 & $68 \%$ & 7 & $44 \%$ & 12 & $75 \%$ & 21 & $55 \%$ \\
\hline Atezolizumab, $\mathbf{N}(\%)$ & 5 & $9 \%$ & 3 & $8 \%$ & 2 & $13 \%$ & 1 & $6 \%$ & 4 & $11 \%$ \\
\hline Pembrolizumab, $\mathbf{N}(\%)$ & 10 & $19 \%$ & 5 & $13 \%$ & 5 & $31 \%$ & 2 & $13 \%$ & 8 & $21 \%$ \\
\hline Ipilimumab, N (\%) & 19 & $35 \%$ & 12 & $32 \%$ & 7 & $44 \%$ & 5 & $31 \%$ & 14 & $37 \%$ \\
\hline Durvalumab, $\mathbf{N}(\%)$ & 0 & $0 \%$ & 0 & $0 \%$ & 0 & $0 \%$ & 0 & $0 \%$ & 0 & $0 \%$ \\
\hline Cemiplimab, $\mathbf{N}(\%)$ & 1 & $2 \%$ & 1 & $3 \%$ & 0 & $0 \%$ & 1 & $6 \%$ & 0 & $0 \%$ \\
\hline Dual ICPI therapy, $\mathbf{N}(\%)$ & 14 & $26 \%$ & 9 & $24 \%$ & 5 & $31 \%$ & 4 & $25 \%$ & 10 & $26 \%$ \\
\hline $\begin{array}{l}\text { Onset from 1st dose, days, median } \\
\text { (range) }\end{array}$ & 58 & $3-450$ & 58 & 3-450 & 63 & $4-450$ & 56 & $3-240$ & 60 & $3-450$ \\
\hline $\begin{array}{l}\text { Onset from last dose, days, } \\
\text { median (range) }\end{array}$ & 10 & $1-438$ & 9,5 & $1-96$ & 12 & $4-438$ & 5 & $3-30$ & 12,5 & $1-438$ \\
\hline Cycles prior to onset, median, & 3 & 1-14 & 3 & 1-14 & 2,5 & $1-11$ & 3 & $1-8$ & 4 & $1-14$ \\
\hline
\end{tabular}


medRxiv preprint doi: https://doi.org/10.1101/2020.08.31.20185009; this version posted September 2, 2020. The copyright holder for this preprint (which was not certified by peer review) is the author/funder, who has granted medRxiv a license to display the preprint in perpetuity.

\section{It is made available under a CC-BY-ND 4.0 International license .}

\begin{tabular}{|c|c|c|c|c|c|c|c|c|c|c|}
\hline (range) & & & & & & & & & & \\
\hline \multicolumn{11}{|l|}{ Cancer response to ICPI } \\
\hline Complete remission, $\mathrm{N}(\%)$ & 5 & $9 \%$ & 4 & $11 \%$ & 1 & $6 \%$ & 0 & $0 \%$ & 5 & $13 \%$ \\
\hline Positive response, $\mathrm{N}(\%)$ & 16 & $30 \%$ & 13 & $34 \%$ & 3 & $19 \%$ & 8 & $50 \%$ & 8 & $21 \%$ \\
\hline Progression, $\mathrm{N}(\%)$ & 12 & $22 \%$ & 6 & $16 \%$ & 6 & $38 \%$ & 2 & $13 \%$ & 10 & $26 \%$ \\
\hline Not described, $\mathrm{N}(\%)$ & 21 & $39 \%$ & 15 & $39 \%$ & 6 & $38 \%$ & 6 & $38 \%$ & 15 & $39 \%$ \\
\hline \multicolumn{11}{|l|}{ Other ICPI induced AE } \\
\hline total, N, (\%) & 10 & $19 \%$ & 9 & $24 \%$ & 1 & $6 \%$ & 4 & $25 \%$ & 6 & $16 \%$ \\
\hline Hypophysitis, N (\%) & 4 & $40 \%$ & 4 & $44 \%$ & 0 & $0 \%$ & 1 & $25 \%$ & 3 & $50 \%$ \\
\hline Skin rash or vitiligo, $\mathbf{N}(\%)$ & 3 & $30 \%$ & 2 & $22 \%$ & 1 & $100 \%$ & 1 & $25 \%$ & 2 & $33 \%$ \\
\hline Neuromuscular deficits, $\mathrm{N}$ (\%) & 2 & $20 \%$ & 2 & $22 \%$ & 0 & $0 \%$ & 1 & $25 \%$ & 1 & $17 \%$ \\
\hline Other, $\mathbf{N}$ & 7 & - & 5 & - & 2 & - & 2 & - & 5 & - \\
\hline \multicolumn{11}{|c|}{$\begin{array}{l}\text { Basic demographics, cancer diagnoses and immune check-point inhibitor treatment characteristics of total population } \\
\text { and subgroups of patients with and without brain metastases, and with and without limbic autoimmune encephalitis } \\
\text { Abbreviations: AE, adverse events; } \mathrm{AIE} \text {, autoimmune encephalitis; ICPI, immune check-point inhibitor; N, numbers } \\
\text { NSCLC, non-small cell lung cancer; } \mathrm{SCLC} \text {, small cell lung cancer. }\end{array}$} \\
\hline
\end{tabular}


medRxiv preprint doi: https://doi.org/10.1101/2020.08.31.20185009; this version posted September 2, 2020. The copyright holder for this preprint (which was not certified by peer review) is the author/funder, who has granted medRxiv a license to display the preprint in perpetuity.

It is made available under a CC-BY-ND 4.0 International license .

\begin{tabular}{|c|c|c|c|c|c|c|c|c|c|c|}
\hline \multirow[b]{2}{*}{ General clinical findings } & \multicolumn{2}{|c|}{ Total } & \multicolumn{2}{|c|}{$\begin{array}{l}\text { Without brain } \\
\text { metastases } \\
\text { (N=38) }\end{array}$} & \multicolumn{2}{|c|}{$\begin{array}{l}\text { With brain } \\
\text { metastases } \\
(N=16)\end{array}$} & \multicolumn{2}{|c|}{$\begin{array}{l}\text { Limbic AIE } \\
(N=16)\end{array}$} & \multicolumn{2}{|c|}{$\begin{array}{l}\text { Non limbic AIE } \\
(\mathrm{N}=\mathbf{3 8})\end{array}$} \\
\hline & & & & & & & & & & \\
\hline Subacute onset, $\mathrm{N}(\%)$ & 50 & $93 \%$ & 37 & $97 \%$ & 13 & $81 \%$ & 15 & $94 \%$ & 35 & $92 \%$ \\
\hline Working memory deficit, N (\%) & 15 & $28 \%$ & 10 & $26 \%$ & 5 & $31 \%$ & 11 & $69 \%$ & 4 & $11 \%$ \\
\hline Altered mental status, $\mathbf{N}(\%)$ & 46 & $85 \%$ & 31 & $82 \%$ & 15 & $94 \%$ & 13 & $81 \%$ & 33 & $87 \%$ \\
\hline Dyskinesia, N (\%) & 6 & $11 \%$ & 3 & $8 \%$ & 3 & $19 \%$ & 1 & $6 \%$ & 5 & $13 \%$ \\
\hline Focal CNS findings, $\mathrm{N}$ (\%) & 34 & $63 \%$ & 23 & $61 \%$ & 11 & $69 \%$ & 11 & $69 \%$ & 23 & $61 \%$ \\
\hline Ataxia, $\mathbf{N}(\%)$ & 10 & $19 \%$ & 6 & $16 \%$ & 4 & $25 \%$ & 5 & $31 \%$ & 5 & $13 \%$ \\
\hline Psychiatric symptoms & 20 & $37 \%$ & 13 & $34 \%$ & 7 & $44 \%$ & 8 & $50 \%$ & 12 & $32 \%$ \\
\hline Hallucinations, $\mathbf{N}(\%)^{2}$ & 4 & $20 \%$ & 3 & $23 \%$ & 1 & $14 \%$ & 0 & $0 \%$ & 4 & $33 \%$ \\
\hline Behavioral disorders, $\mathbf{N}(\%)^{a}$ & 11 & $55 \%$ & 6 & $46 \%$ & 5 & $71 \%$ & 5 & $63 \%$ & 6 & $50 \%$ \\
\hline Paranoia, $\mathbf{N},(\%)^{a}$ & 2 & $10 \%$ & 2 & $15 \%$ & 0 & $0 \%$ & 1 & $13 \%$ & 1 & $8 \%$ \\
\hline Affective, $\mathrm{N}(\%)^{\mathrm{a}}$ & 7 & $35 \%$ & 6 & $46 \%$ & 1 & $14 \%$ & 2 & $25 \%$ & 5 & $42 \%$ \\
\hline Seizures & 18 & $33 \%$ & 12 & $32 \%$ & 6 & $38 \%$ & 6 & $38 \%$ & 12 & $32 \%$ \\
\hline Generalized convulsive, $\mathbf{N}(\%)^{b}$ & 7 & $39 \%$ & 4 & $33 \%$ & 3 & $50 \%$ & 4 & $67 \%$ & 3 & $25 \%$ \\
\hline Focal, $\mathbf{N},(\%)^{\mathrm{b}}$ & 5 & $28 \%$ & 5 & $42 \%$ & 0 & $0 \%$ & 1 & $17 \%$ & 4 & $33 \%$ \\
\hline Generalized + focal, $N(\%)^{b}$ & 2 & $11 \%$ & 0 & $0 \%$ & 2 & $33 \%$ & 1 & $17 \%$ & 1 & $8 \%$ \\
\hline NCSE, N $(\%)^{b}$ & 4 & $22 \%$ & 3 & $25 \%$ & 1 & $17 \%$ & 0 & $0 \%$ & 4 & $33 \%$ \\
\hline Autonomic dysfunction & 18 & $33 \%$ & 13 & $34 \%$ & 5 & $31 \%$ & 5 & $31 \%$ & 14 & $37 \%$ \\
\hline Central hypoventilation, $\mathrm{N}(\%)^{\mathrm{c}}$ & 2 & $11 \%$ & 2 & $15 \%$ & 0 & $0 \%$ & 2 & $40 \%$ & 0 & $0 \%$ \\
\hline Fever, $\mathbf{N}(\%)^{c}$ & 12 & $67 \%$ & 8 & $62 \%$ & 4 & $80 \%$ & 1 & $20 \%$ & 11 & $79 \%$ \\
\hline Other, $\mathbf{N}(\%)^{\mathrm{c}}$ & 4 & $22 \%$ & 3 & $23 \%$ & 1 & $20 \%$ & 2 & $40 \%$ & 3 & $21 \%$ \\
\hline \multicolumn{11}{|l|}{ Other } \\
\hline Hyperphagia, N (\%) & 3 & $6 \%$ & 2 & $5 \%$ & 1 & $6 \%$ & 1 & $6 \%$ & 2 & $5 \%$ \\
\hline Narcolepsy, N (\%) & 1 & $2 \%$ & 1 & $3 \%$ & 0 & $0 \%$ & 1 & $6 \%$ & 0 & $0 \%$ \\
\hline \multicolumn{11}{|c|}{$\begin{array}{l}\text { Overview of symptomatology and clinical signs in the total population and subgroups of patients with and without } \\
\text { brain metastases, and with and without limbic autoimmune encephalitis. Abbreviations: AlE, autoimmune } \\
\text { encephalitis; N, numbers; NCSE, non-convulsive status epilepticus. }{ }^{a, b, c} \text { Percentage refers to number of patients with } \\
\text { specific symptom out of general symptom-group of psychiatric }{ }^{a} \text {, seizures }{ }^{b} \text { or autonomic dysfunction }{ }^{c}\end{array}$} \\
\hline
\end{tabular}


medRxiv preprint doi: https://doi.org/10.1101/2020.08.31.20185009; this version posted September 2, 2020. The copyright holder for this preprint (which was not certified by peer review) is the author/funder, who has granted medRxiv a license to display the preprint in perpetuity.

It is made available under a CC-BY-ND 4.0 International license.

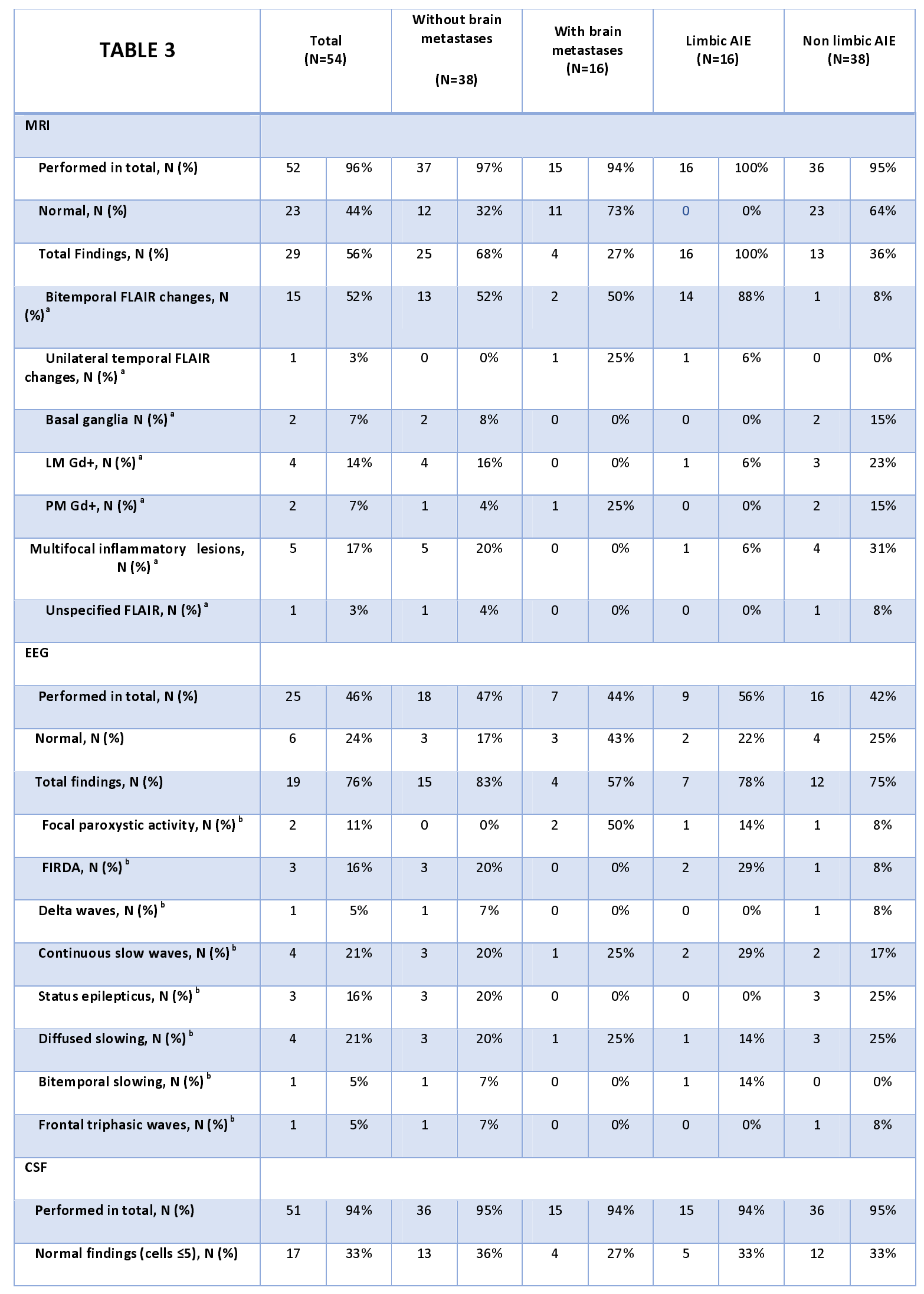


medRxiv preprint doi: https://doi.org/10.1101/2020.08.31.20185009; this version posted September 2, 2020. The copyright holder for this preprint (which was not certified by peer review) is the author/funder, who has granted medRxiv a license to display the preprint in perpetuity.

\section{It is made available under a CC-BY-ND 4.0 International license.}

\begin{tabular}{|c|c|c|c|c|c|c|c|c|c|c|}
\hline Pleocytosis (cells >5), N (\%) & 34 & $67 \%$ & 23 & $64 \%$ & 11 & $73 \%$ & 10 & $67 \%$ & 24 & $67 \%$ \\
\hline Cell count, median $(\mathrm{N} / \mu \mathrm{L})$ & 18,5 & $2-705$ & 17 & $2-553$ & 19,5 & $8-705$ & 16 & 3-19 & 53 & $2-705$ \\
\hline 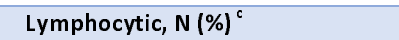 & 23 & $68 \%$ & 15 & $65 \%$ & 8 & $73 \%$ & 6 & $60 \%$ & 17 & $71 \%$ \\
\hline Granulocytic, $\mathbf{N}(\%)^{\mathrm{c}}$ & 4 & $12 \%$ & 3 & $13 \%$ & 1 & $9 \%$ & 0 & $0 \%$ & 4 & $17 \%$ \\
\hline Not differentiated, $\mathbf{N}(\%)^{\mathrm{c}}$ & 7 & $21 \%$ & 5 & $22 \%$ & 2 & $18 \%$ & 4 & $40 \%$ & 3 & $13 \%$ \\
\hline $\begin{array}{l}\text { Protein levels (mg/dL), median } \\
\text { (range) }\end{array}$ & 101 & $33-980$ & 90 & $33-980$ & 151 & $79-446$ & 90 & $33-600$ & 104 & $38-600$ \\
\hline Oligoclonal bands tested, $\mathbf{N}(\%)$ & 17 & $33 \%$ & 13 & $36 \%$ & 4 & $27 \%$ & 9 & $60 \%$ & 8 & $22 \%$ \\
\hline Positive, N (\%) ${ }^{d}$ & 9 & $53 \%$ & 7 & $54 \%$ & 2 & $50 \%$ & 4 & $44 \%$ & 5 & $63 \%$ \\
\hline Negative, $\mathbf{N}(\%)^{d}$ & 8 & $47 \%$ & 6 & $46 \%$ & 2 & $50 \%$ & 5 & $56 \%$ & 3 & $38 \%$ \\
\hline \multicolumn{11}{|l|}{ Other } \\
\hline $\begin{array}{l}\text { Tested for malignant cells in CSF } \\
\text { (positive), } \mathrm{N}(\%)\end{array}$ & $21(0)$ & $\begin{array}{l}42 \% \\
(0 \%)\end{array}$ & 14 & $\begin{array}{l}40 \% \\
(0 \%)\end{array}$ & 7 & $\begin{array}{l}47 \% \\
(0 \%)\end{array}$ & 6 & $\begin{array}{l}40 \% \\
(0 \%)\end{array}$ & 15 & $\begin{array}{l}42 \% \\
(0 \%)\end{array}$ \\
\hline Screened viral CNS infection, $N$ (\%) & 32 & $63 \%$ & 19 & $53 \%$ & 13 & $87 \%$ & 14 & $93 \%$ & 18 & $50 \%$ \\
\hline $\begin{array}{l}\text { Screened bacterial CNS infection, N } \\
\text { (\%) }\end{array}$ & 32 & $63 \%$ & 19 & $53 \%$ & 13 & $87 \%$ & 14 & $93 \%$ & 18 & $50 \%$ \\
\hline
\end{tabular}

Laboratory findings in of total population and subgroups of patients with and without brain metastases, and with and without limbic autoimmune encephalitis. Abbreviations: AIE, autoimmune encephalitis; CNS, central nerve system; FLAIR, fluid-attenuated inversion recovery lesion on magnetic resonance scanning; MRI, magnetic resonance imaging; EEG, electroencephalogram; CSF, cerebrospinal fluid; LM, leptomeningeal; PM, pachymeningeal; Gd+, gadolinium contrast enhancement; FIRDA, frontal intermittent rhythmic delta activity. ${ }^{a}$ Percentage refers to number of patients with specific MRI finding out of total MRI findings; ${ }^{b}$ percentage refers to number of patients with specific EEG finding out of total EEG findings; ${ }^{c}$ percentage refers to number of patients with specific cell differentiation out of total with CSF pleocytosis; ${ }^{d}$ percentage refers to number of patients positive or negative out of total tested 
medRxiv preprint doi: https://doi.org/10.1101/2020.08.31.20185009; this version posted September 2, 2020. The copyright holder for this preprint (which was not certified by peer review) is the author/funder, who has granted medRxiv a license to display the preprint in perpetuity.

It is made available under a CC-BY-ND 4.0 International license .

\begin{tabular}{|c|c|c|c|c|c|c|c|c|c|c|c|c|c|c|c|c|c|c|c|c|}
\hline \multirow{3}{*}{$\begin{array}{l}\text { TABLE } 4 \\
\\
\begin{array}{l}\text { Antibody test } \\
\text { performed in } \\
\text { total, } \mathrm{N}(\%)\end{array}\end{array}$} & \multicolumn{4}{|c|}{$\begin{array}{l}\text { Total } \\
(\mathrm{N}=54)\end{array}$} & \multicolumn{4}{|c|}{$\begin{array}{l}\text { Without brain } \\
\text { metastases } \\
(\mathrm{N}=38)\end{array}$} & \multicolumn{4}{|c|}{$\begin{array}{l}\text { With brain } \\
\text { metastases } \\
\qquad(\mathrm{N}=16)\end{array}$} & \multicolumn{4}{|c|}{$\begin{array}{l}\text { Limbic AIE } \\
\qquad(N=16)\end{array}$} & \multicolumn{4}{|c|}{$\begin{array}{l}\text { Non limbic AIE } \\
\qquad(\mathrm{N}=38)\end{array}$} \\
\hline & \multicolumn{2}{|c|}{ CSF } & \multicolumn{2}{|c|}{ Blood } & \multicolumn{2}{|c|}{ CSF } & \multicolumn{2}{|c|}{ Blood } & \multicolumn{2}{|c|}{ CSF } & \multicolumn{2}{|c|}{ Blood } & \multicolumn{2}{|c|}{ CSF } & \multicolumn{2}{|c|}{ Blood } & \multicolumn{2}{|c|}{ CSF } & \multicolumn{2}{|c|}{ Blood } \\
\hline & 31 & $57 \%$ & 25 & $46 \%$ & 21 & $55 \%$ & 18 & $47 \%$ & 10 & $63 \%$ & 7 & $44 \%$ & 12 & $75 \%$ & 12 & $75 \%$ & 19 & $50 \%$ & 13 & $34 \%$ \\
\hline Negative, $\mathrm{N}(\%)$ & 14 & $45 \%$ & 13 & $52 \%$ & 9 & $43 \%$ & 12 & $67 \%$ & 5 & $50 \%$ & 1 & $14 \%$ & 3 & $25 \%$ & 4 & $33 \%$ & 11 & $58 \%$ & 9 & $69 \%$ \\
\hline $\begin{array}{l}\text { Positive findings, } \\
\text { N (\%) }\end{array}$ & 17 & $55 \%$ & 12 & $48 \%$ & 12 & $57 \%$ & 6 & $33 \%$ & 5 & $50 \%$ & 6 & $86 \%$ & 9 & $75 \%$ & 8 & $67 \%$ & 8 & $42 \%$ & 4 & $31 \%$ \\
\hline \multicolumn{21}{|l|}{$\begin{array}{l}\text { Cell surface } \\
\text { antigens }^{2}\end{array}$} \\
\hline NMDA & 2 & $12 \%$ & 1 & $8 \%$ & 0 & $0 \%$ & 0 & $0 \%$ & 2 & $40 \%$ & 1 & $17 \%$ & 0 & $0 \%$ & 0 & $0 \%$ & 2 & $25 \%$ & 1 & $25 \%$ \\
\hline CASPR2 & 1 & $6 \%$ & 1 & $8 \%$ & 1 & $8 \%$ & 1 & $17 \%$ & 0 & $0 \%$ & 0 & $0 \%$ & 1 & $11 \%$ & 1 & $13 \%$ & 0 & $0 \%$ & 0 & $0 \%$ \\
\hline LGI1 & 0 & $0 \%$ & 0 & $0 \%$ & 0 & $0 \%$ & 0 & $0 \%$ & 0 & $0 \%$ & 0 & $0 \%$ & 0 & $0 \%$ & 0 & $0 \%$ & 0 & $0 \%$ & 0 & $0 \%$ \\
\hline \multicolumn{21}{|l|}{$\begin{array}{l}\text { Intracellular } \\
\text { antigens }{ }^{2}\end{array}$} \\
\hline Anti-Hu ${ }^{b}$ & 2 & $12 \%$ & 2 & $17 \%$ & 2 & $17 \%$ & 0 & $0 \%$ & 0 & $0 \%$ & 2 & $33 \%$ & 2 & $22 \%$ & 2 & $25 \%$ & 0 & $0 \%$ & 0 & $0 \%$ \\
\hline anti-Ma2 & 8 & $47 \%$ & 5 & $42 \%$ & 6 & $50 \%$ & 5 & $83 \%$ & 2 & $40 \%$ & 0 & $0 \%$ & 4 & $44 \%$ & 3 & $38 \%$ & 4 & $50 \%$ & 2 & $50 \%$ \\
\hline Anti-GAD & 2 & $12 \%$ & 1 & $8 \%$ & 1 & $8 \%$ & 0 & $0 \%$ & 1 & $20 \%$ & 1 & $17 \%$ & 2 & $22 \%$ & 1 & $13 \%$ & 0 & $0 \%$ & 0 & $0 \%$ \\
\hline Anti-Ri & 1 & $6 \%$ & 0 & $0 \%$ & 1 & $8 \%$ & 0 & $0 \%$ & 0 & $0 \%$ & 0 & $0 \%$ & 0 & $0 \%$ & 0 & $0 \%$ & 1 & $13 \%$ & 0 & $0 \%$ \\
\hline AGNA & 0 & $0 \%$ & 1 & $8 \%$ & 0 & $0 \%$ & 0 & $0 \%$ & 0 & $0 \%$ & 1 & $17 \%$ & 0 & $0 \%$ & 1 & $13 \%$ & 0 & $0 \%$ & 0 & $0 \%$ \\
\hline $\begin{array}{l}\text { Purkinje cell, } \\
\text { unspecified }^{\text {b }}\end{array}$ & 1 & $6 \%$ & 1 & $8 \%$ & 1 & $8 \%$ & 0 & $0 \%$ & 0 & $0 \%$ & 1 & $17 \%$ & 1 & $11 \%$ & 0 & $0 \%$ & 0 & $0 \%$ & 1 & $25 \%$ \\
\hline \multicolumn{21}{|l|}{ Other ${ }^{a}$} \\
\hline TPO & 0 & $0 \%$ & 1 & $8 \%$ & 0 & $0 \%$ & 1 & $3 \%$ & 0 & $0 \%$ & 0 & $0 \%$ & 0 & $0 \%$ & 0 & $0 \%$ & 0 & $0 \%$ & 1 & $3 \%$ \\
\hline Unclassified & 1 & $6 \%$ & 0 & $0 \%$ & 1 & $8 \%$ & 0 & $0 \%$ & 0 & $0 \%$ & 0 & $0 \%$ & 0 & $0 \%$ & 0 & $0 \%$ & 1 & $13 \%$ & 0 & $0 \%$ \\
\hline \multicolumn{21}{|c|}{$\begin{array}{l}\text { Antibody testing in cerebrospinal fluid and blood in the total population and subgroups of patients with and without } \\
\text { brain metastases, and with and without limbic autoimmune encephalitis. Abbreviations: AlE, autoimmune } \\
\text { encephalitis; CSF, cerebrospinal fluid; NMDA, anti-N-methyl D-aspartate; CASPR2, contactin-associated protein-like } \\
\text { 2; LGI1, leucine-rich glioma-inactivated } 1 \text {; GAD, glutamate decarboxylase; AGNA, anti-glial nuclear antibody; TPO, } \\
\text { thyroid peroxidase. a Percentage refers to number of patients with specific antibody out of total with positive } \\
\text { findings; }{ }^{b} \text { one patient with both anti-Hu and an unspecified Purkinje cell antibody }\end{array}$} \\
\hline
\end{tabular}


medRxiv preprint doi: https://doi.org/10.1101/2020.08.31.20185009; this version posted September 2, 2020. The copyright holder for this preprint (which was not certified by peer review) is the author/funder, who has granted medRxiv a license to display the preprint in perpetuity.

It is made available under a CC-BY-ND 4.0 International license .

\begin{tabular}{|c|c|c|c|c|c|c|c|c|c|c|}
\hline TABLE 5 & \multicolumn{2}{|c|}{$\begin{array}{l}\text { Total } \\
\text { (N=54) }\end{array}$} & \multicolumn{2}{|c|}{$\begin{array}{c}\text { Without brain } \\
\text { metastases ( } \mathrm{N}=38 \text { ) }\end{array}$} & \multicolumn{2}{|c|}{$\begin{array}{c}\text { With brain } \\
\text { metastases } \\
(N=16)\end{array}$} & \multicolumn{2}{|c|}{$\begin{array}{l}\text { Limbic AIE } \\
\text { (N=16) }\end{array}$} & \multicolumn{2}{|c|}{$\begin{array}{l}\text { Non limbic AIE } \\
(\mathrm{N}=\mathbf{3 8})\end{array}$} \\
\hline 1st line therapy initiated, $\mathrm{N}(\%)$ & 51 & $94 \%$ & 36 & $95 \%$ & 15 & $94 \%$ & 16 & $100 \%$ & 35 & $92 \%$ \\
\hline \multicolumn{11}{|l|}{ Steroids ${ }^{a}$} \\
\hline No additional steroids, $\mathbf{N}(\%)$ & 3 & $6 \%$ & 2 & $5 \%$ & 1 & $6 \%$ & 0 & $0 \%$ & 3 & $8 \%$ \\
\hline Oral steroids, N (\%) & 4 & $7 \%$ & 1 & $3 \%$ & 3 & $19 \%$ & 1 & $6 \%$ & 3 & $8 \%$ \\
\hline IV pulse moderate dose, $\mathrm{N}(\%)$ & 12 & $22 \%$ & 10 & $26 \%$ & 2 & $13 \%$ & 2 & $13 \%$ & 10 & $26 \%$ \\
\hline IV pulse high dose, $\mathbf{N}(\%)$ & 23 & $43 \%$ & 16 & $42 \%$ & 7 & $44 \%$ & 8 & $50 \%$ & 15 & $39 \%$ \\
\hline Dose not described, $\mathbf{N}(\%)$ & 12 & $22 \%$ & 9 & $24 \%$ & 3 & $19 \%$ & 5 & $31 \%$ & 7 & $18 \%$ \\
\hline IVIG, yes, $\mathbf{N}(\%)^{\mathrm{a}}$ & 15 & $28 \%$ & 9 & $24 \%$ & 6 & $38 \%$ & 4 & $25 \%$ & 11 & $29 \%$ \\
\hline PEX, yes, $\mathrm{N}(\%)^{\mathrm{a}}$ & 7 & $13 \%$ & 6 & $17 \%$ & 1 & $6 \%$ & 4 & $25 \%$ & 3 & $8 \%$ \\
\hline \multicolumn{11}{|l|}{ Outcome after 1st line therapy ${ }^{b}$} \\
\hline improvement, $\mathbf{N}(\%)$ & 35 & $69 \%$ & 25 & $69 \%$ & 10 & $67 \%$ & 8 & $50 \%$ & 27 & $77 \%$ \\
\hline progression, $\mathrm{N}(\%)$ & 14 & $27 \%$ & 9 & $25 \%$ & 5 & $33 \%$ & 7 & $44 \%$ & 7 & $20 \%$ \\
\hline No change in symptoms, $\mathrm{N}(\%)$ & 2 & $4 \%$ & 2 & $6 \%$ & 0 & $0 \%$ & 1 & $6 \%$ & 1 & $3 \%$ \\
\hline 2nd line therapy initiated, $\mathrm{N}$ (\%) & 14 & $26 \%$ & 11 & $29 \%$ & 3 & $25 \%$ & 7 & $44 \%$ & 7 & $18 \%$ \\
\hline Rituximab, $\mathbf{N}(\%)^{c}$ & 8 & $57 \%$ & 6 & $55 \%$ & 2 & $50 \%$ & 4 & $57 \%$ & 4 & $57 \%$ \\
\hline Natalizumab, $\mathbf{N}(\%)^{\mathrm{c}}$ & 1 & $7 \%$ & 1 & $9 \%$ & 0 & $0 \%$ & 1 & $14 \%$ & 0 & $0 \%$ \\
\hline Cyclophophamid, $\mathbf{N}(\%)^{c}$ & 2 & $14 \%$ & 1 & $9 \%$ & 1 & $25 \%$ & 0 & $0 \%$ & 2 & $29 \%$ \\
\hline Infliximab, N (\%) ${ }^{c}$ & 2 & $14 \%$ & 2 & $18 \%$ & 0 & $0 \%$ & 0 & $0 \%$ & 2 & $29 \%$ \\
\hline Azathioprin, $\mathrm{N}(\%)^{\mathrm{c}}$ & 1 & $7 \%$ & 1 & $9 \%$ & 0 & $0 \%$ & 1 & $14 \%$ & 0 & $0 \%$ \\
\hline Mycophenolate, $\mathrm{N}(\%)^{\mathrm{c}}$ & 1 & $7 \%$ & 1 & $9 \%$ & 0 & $0 \%$ & 1 & $14 \%$ & 0 & $0 \%$ \\
\hline \multicolumn{11}{|l|}{ Outcome after 2 nd line therapy } \\
\hline 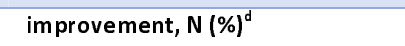 & 7 & $50 \%$ & 4 & $36 \%$ & 3 & $100 \%$ & 3 & $43 \%$ & 4 & $57 \%$ \\
\hline progression, $\mathbf{N}(\%)^{d}$ & 5 & $36 \%$ & 5 & $45 \%$ & 0 & $0 \%$ & 3 & $43 \%$ & 2 & $29 \%$ \\
\hline No change in symptoms, $\mathrm{N}(\%)^{d}$ & 2 & $14 \%$ & 2 & $18 \%$ & 0 & $0 \%$ & 1 & $14 \%$ & 1 & $14 \%$ \\
\hline \multicolumn{11}{|l|}{ Admission, ICU, relapse and mortality } \\
\hline $\begin{array}{l}\text { Admission duration, days, median } \\
\text { (range) }\end{array}$ & 21 & $5-182$ & 23,5 & $5-90$ & 21 & $7-182$ & 26 & $7-26$ & 21 & $5-182$ \\
\hline ICU treatment, Yes, $\mathrm{N}(\%)$ & 9 & $17 \%$ & 7 & $18 \%$ & 2 & $13 \%$ & 3 & $19 \%$ & 6 & $16 \%$ \\
\hline
\end{tabular}


medRxiv preprint doi: https://doi.org/10.1101/2020.08.31.20185009; this version posted September 2, 2020. The copyright holder for this preprint (which was not certified by peer review) is the author/funder, who has granted medRxiv a license to display the preprint in perpetuity.

It is made available under a CC-BY-ND 4.0 International license .

\begin{tabular}{|c|c|c|c|c|c|c|c|c|c|c|}
\hline Relapse of AIE, $N(\%)$ & 5 & $9 \%$ & 5 & $13 \%$ & 0 & $0 \%$ & 3 & $19 \%$ & 2 & $5 \%$ \\
\hline Sequalae total, $\mathbf{N}(\%)$ & 14 & $26 \%$ & 10 & $26 \%$ & 4 & $25 \%$ & 6 & $38 \%$ & 8 & $21 \%$ \\
\hline Sequalae, cognitive, $\mathbf{N}(\%)^{\mathrm{e}}$ & 11 & $79 \%$ & 8 & $80 \%$ & 3 & $75 \%$ & 5 & $83 \%$ & 6 & $75 \%$ \\
\hline Sequalae, epilepsy, $N(\%)^{e}$ & 2 & $14 \%$ & 2 & $20 \%$ & 0 & $0 \%$ & 2 & $33 \%$ & 0 & $0 \%$ \\
\hline Sequalae, others, $\mathbf{N}(\%)^{e}$ & 7 & $50 \%$ & 4 & $40 \%$ & 3 & $75 \%$ & 2 & $33 \%$ & 5 & $63 \%$ \\
\hline Death of/with AIE, N (\%) & 10 & $19 \%$ & 8 & $21 \%$ & 2 & $13 \%$ & 5 & $31 \%$ & 5 & $13 \%$ \\
\hline Death, cancer induced, $\mathbf{N}(\%)$ & 9 & $17 \%$ & 5 & $13 \%$ & 4 & $25 \%$ & 4 & $25 \%$ & 5 & $13 \%$ \\
\hline \multicolumn{11}{|c|}{$\begin{array}{l}\text { Treatment and outcome of total population and subgroups of patients with and without brain metastases, and with and } \\
\text { without limbic autoimmune encephalitis. Abbreviations: AIE, Autoimmune encephalitis; IV, intravenous; IVIG, IV } \\
\text { immunoglobulin; PEX, plasma exchange therapy: ICU, intensive care unit. }{ }^{\text {a }} \text { Percentage refers to number of patients with } \\
\text { specific treatment out of total of patients who received } 1^{\text {st }} \text { line therapy defined as steroids, IVIG or PEX. All patients with } 1^{\text {st }} \\
\text { line therapy were treated with steroids. }{ }^{b} \text { Percentage refers to number of patients with specific outcome of total treated } \\
\text { with } 1^{\text {st }} \text { line therapy; }{ }^{\text {c }} \text { percentage refers to number of patients with specific treatment out of total of patients who received } \\
2^{\text {nd }} \text { line therapy; }{ }^{d} \text { percentage refers to number of patients with specific outcome of total treated with } 2^{\text {nd }} \text { line therapy; }{ }^{\text {dine }} \text { the } \\
\text { percentage refers to number of patients with specific sequalae out of total sequalae }\end{array}$} \\
\hline
\end{tabular}


medRxiv preprint doi: https://doi.org/10.1101/2020.08.31.20185009; this version posted September 2, 2020. The copyright holder for this preprint (which was not certified by peer review) is the author/funder, who has granted medRxiv a license to display the preprint in perpetuity.

\section{It is made available under a CC-BY-ND 4.0 International license .}

\begin{tabular}{|c|c|c|c|c|c|}
\hline TABLE 6 & Possible AIE & $\begin{array}{c}\text { Definite } \\
\text { limbic AIE }\end{array}$ & $\begin{array}{l}\text { No criteria } \\
\text { for AlE }\end{array}$ & $\begin{array}{l}\text { Definite anit- } \\
\text { NMDA }\end{array}$ & $\begin{array}{l}\text { ADEM, SREAT } \\
\text { or Ab neg AIE }\end{array}$ \\
\hline Total in group, $\mathbf{N}$ & 23 & 16 & 9 & 2 & 4 \\
\hline MRI findings, total, N (\%) & $6(26 \%)$ & $16(100 \%)$ & $4(44 \%)$ & $0(0 \%)$ & $3(75 \%)$ \\
\hline Bitemporal FLAIR changes, $\mathrm{N}(\%)$ & $0(0 \%)$ & $14(88 \%)$ & $1(11 \%)$ & - & $0(0 \%)$ \\
\hline Meningeal enhancement, $\mathrm{N}$ (\%) & $4(17 \%)$ & $1(6 \%)$ & $1(11 \%)$ & - & $0(0 \%)$ \\
\hline Multifocal infla mmatory lesions, $\mathrm{N}(\%)$ & $0(0 \%)$ & $1(6 \%)$ & $1(11 \%)$ & - & $3(75 \%)$ \\
\hline Other, $\mathrm{N}(\%)$ & $2(9 \%)$ & $1(6 \%)$ & $1(11 \%)$ & - & $0(0 \%)$ \\
\hline EEG findings, $N(\%)$ & $9(39 \%)$ & $7(44 \%)$ & $1(11 \%)$ & $1(50 \%)$ & $2(50 \%)$ \\
\hline $\begin{array}{l}\text { Delta waves, continuous or diffused } \\
\text { slowing, } \mathrm{N}(\%)\end{array}$ & $5(22 \%)$ & $3(19 \%)$ & $1(11 \%)$ & $0(0 \%)$ & $1(25 \%)$ \\
\hline FIRDA, N (\%) & $0(0 \%)$ & $2(13 \%)$ & $0(0 \%)$ & $0(0 \%)$ & $1(25 \%)$ \\
\hline Status epilepticus, N (\%) & $3(13 \%)$ & $0(0 \%)$ & $0(0 \%)$ & $0(0 \%)$ & $0(0 \%)$ \\
\hline Other, N (\%) & $1(4 \%)$ & $2(13 \%)$ & $0(0 \%)$ & $1(50 \%)$ & $0(0 \%)$ \\
\hline CSF Pleocytosis (> 5 cells), N (\%) & $16(70 \%)$ & $10(63 \%)$ & $3(33 \%)$ & $2(100 \%)$ & $3(75 \%)$ \\
\hline Intracellular antibodies in CSF, N (\%) ${ }^{a}$ & $2(9 \%)$ & $8(50 \%)$ & $3(33 \%)$ & $0(0 \%)$ & $0(0 \%)$ \\
\hline Cell-surface antibodies in CSF, $\mathrm{N}$ (\%) & $0(0 \%)$ & $1(6 \%)$ & $0(0 \%)$ & $2(100 \%)$ & $0(0 \%)$ \\
\hline Improvement after 1st-line therapy, $\mathrm{N}$ (\%) & $18(78 \%)$ & $8(50 \%)$ & $5(56 \%)$ & $1(50 \%)$ & $3(75 \%)$ \\
\hline Death caused by AIE & $2(9 \%)$ & $5(31 \%)$ & $3(33 \%)$ & $0(0 \%)$ & $0(0 \%)$ \\
\hline \multicolumn{6}{|c|}{ 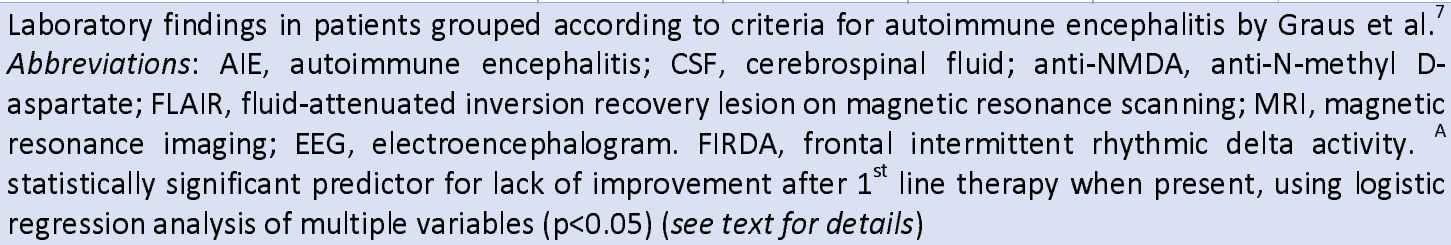 } \\
\hline
\end{tabular}


medRxiv preprint doi: https://doi.org/10.1101/2020.08.31.20185009; this version posted September 2, 2020. The copyright holder for this preprint

(which was not certified by peer review) is the author/funder, who has granted medRxiv a license to display the preprint in perpetuity.

It is made available under a CC-BY-ND 4.0 International license.

\section{Figures}

\section{Figure 1}

Written consent for publication of the case history was obtained from next of kin, but data have been removed on request from medRxiv for confidentiality reasons. However, the interested reader can contact the corresponding author for access to those data.

\section{Figure 2}

Overview of data points extracted from a systematic literature review

\section{Figure S1}

Flowchart of the literature search 





Demographics

- Sex

- Age

- Cancer diagnosis

- ICPI treatment

- Pre-existing CNS

disease

- Cancer response to ICPI treatment
Symptoms and clinical$$
\text { findings }
$$

- Subacute onset $<3$ months

- Memory deficits

- Seizures

- Confusion

- Psychiatric symptoms

- Encephalopathy

- Dyskinesia

- Focal CNS findings

- Autonomic dysfunction

- Other
Treatment

- Steroids

- IVIG

- Plasmapharesis

- Rituximab

- Cyclophosphamid

- Intensive care

- Progression after 1st or

2nd line therapy

- Other
Diagnosis and

outcome

- $\mathrm{mRS}$, discharge and 1 year

- No improvement within

4 weeks

- Relapse of AIE

- Death

- Sequalae

- Possible AIE

- Definite limbic AIE

- Probable NMDA AIE

- Definite NMDA AIE

- Definite ADEM

- Seronegative AIE

- Unlikely AIE 



$(\mathrm{N}=39)$ with 53 patients 